\title{
The hydrogeochemistry of shallow groundwater from Lut Desert, Iran: The hottest place on Earth
}

\author{
W. Berry Lyons ${ }^{\mathrm{a}}$, Susan A. Welch ${ }^{\mathrm{a}, *}$, Christopher B. Gardner ${ }^{\mathrm{a}}$, Arash Sharifi ${ }^{\mathrm{b}}$, Amir AghaKouchak ${ }^{\mathrm{c}}$, \\ Marjan Mashkour $^{\mathrm{d}, \mathrm{e}}$, Morteza Djamali ${ }^{\mathrm{f}}$, Zeinab Matinzadeh ${ }^{\mathrm{b}}$, Sara Palacio ${ }^{\mathrm{g}}$, Hossein Akhani $^{\mathrm{b}}$ \\ ${ }^{a}$ School of Earth Sciences, Byrd Polar and Climate Research Center, The Ohio State University, Columbus OH, 43210, USA \\ ${ }^{\mathrm{b}}$ Halophytes and $C_{4}$ Plants Research Laboratory, Department of Plant Science, School of Biology, University of Tehran, P.O. Box 14155-6455, Tehran, Iran \\ ${ }^{\mathrm{c}}$ Department of Civil and Environmental Engineering, Department of Earth System Science, University of California Irvine, USA \\ ${ }^{\mathrm{d}}$ Archéozoologie, Archéobotanique, UMR 7209, Centre National de Recherche Scientifique(CNRS), Muséum National d'Histoire Naturelle (MNHN), CP55, 55 rue Buffon, \\ 75005, Paris, France \\ ${ }^{\mathrm{e}}$ University of Tehran, Faculty of Environment, Enghelab avenue Ghosd street, Tehran, Iran \\ ${ }^{\mathrm{f}}$ Institut Méditerranéen de Biodiversité et d'Ecologie, Aix-MarseilleUniversité, Avignon Université, CNRS, IRD - Technopôle del'environnement Arbois, Ave. Louis Philibert \\ Bâtiment Villemin - BP 80, 13545, Aix-en-Provence, France \\ ${ }^{\mathrm{g}}$ Instituto Pirenaico de Ecología (IPE-CSIC), Avenida Nuestra Señora de la Victoria 16, 22700, Jaca Huesca, Spain
}

\section{A B S T R A C T}

This paper presents the first shallow groundwater geochemical data from the Lut Desert (Dasht-e-Lut), one of the hottest places on the planet. The waters are Na-Cl brines that have undergone extensive evaporation, but they are unlike seawater derived brines in that the $\mathrm{K}^{+}$is low and the $\mathrm{Ca}^{2+}>\mathrm{Mg}^{2+}$ and $\mathrm{HCO}_{3}{ }^{-}>\mathrm{SO}_{4}{ }^{2-} . \mathrm{In}^{-}$ addition to evapo-concentration, the most saline samples indicate that the dissolution of previously deposited salt also acts as a major control on the geochemistry of these waters. High concentrations of gypsum in surface soils along with the water geochemistry indicate the dissolution, precipitation, and reprecipitation of evaporite salts are very important to the overall chemistry of the near surface environment. As demonstrated by the high $\mathrm{H}_{4} \mathrm{SiO}_{4}$ concentrations, the weathering of aluminosilicate minerals also contributes to the solutes present. Fixed nitrogen $\left(\mathrm{NO}_{3}{ }^{-}+\mathrm{NO}_{2}{ }^{-}\right)$concentrations suggest little to no denitrification is occurring in these waters. The processes controlling the geochemistry of the Lut waters are similar to those in other hyperarid regions of the Earth.

\section{Introduction}

The Lut Desert (Dasht-e-Lut) in southeast Iran is one of the largest deserts in Iran, receiving $<30 \mathrm{~mm}$ of precipitation annually. Its bioclimate is classified has 'tropical hyperdesertic,' the hottest and driest bioclimate in the world in the Global Bioclimatic Classification (Djamali et al., 2011). The region has been referred to as the thermal pole of the Earth and is recognized as one of the hottest, if not the hottest, locations on planet Earth with surface temperatures as high as $70.7{ }^{\circ} \mathrm{C}$ recorded via satellite in the mid 2000's (Mildrexler et al., 2006). A recent measurement during the sampling campaign in Yalan dunes (March 4, 2017) returned skin temperature as high as $78.2{ }^{\circ} \mathrm{C}$ (Trescher, 2017). The mean annual precipitation (7-year average, 2003-2010) recorded at the nearest meteorological station, Shahdad synoptic weather station, located at the west flank of the Lut desert with the altitude of $400 \mathrm{~m}$. a.s.l, does not exceed $30 \mathrm{~mm}$. Precipitation is highest from January through March and the dry season lasts from April to November. Mean annual temperature at the station is $27.5{ }^{\circ} \mathrm{C}$ and the mean minimum and maximum daily air temperatures of the warmest and coldest months of the year are $-2.6{ }^{\circ} \mathrm{C}$ and $50.4{ }^{\circ} \mathrm{C}$ respectively (Fig. S1). Remote sensing analysis from 2002 to 2003 report average daily summer temperatures as high as $45.3-55.7 \mathrm{C}$, with surface soil temperatures as high as 66.5 to 71.1 (Azizi et al., 2007). The Lut Desert has a total area of $\sim 51,800 \mathrm{~km}^{2}$, and consists of sand dunes, ergs, megayardangs (kaluts), desert pavement, as well as large flat areas of salty soils and playas (Alavipanah et al., 2007; Ehsani, 2011). A semi-permanent river (Rud-e Shur) flows from NW of the area and passes the edge of Kaluts and ends in the central depression (Chaleh Markazi).

The Lut Desert is within the Lut Block, whose basement consists of pre-Jurassic metamorphic rocks (pelitic schist) as well as Jurassic sediments intruded by younger (Jurassic to Tertiary) granitic plutons and covered by Tertiary mafic to felsic volcanics (Arjmandzadeh and Santos, 2014; Tirrul et al., 1983; Yazdi et al., 2014). The region is active tectonically with many active faults (Boshrabadi et al., 2018).

A large portion of the region is too harsh for any plants, and has been referred to as aphytic (Mobayen, 1976) and devoid of life. However, recent work has described some of the extremophile microbial life existing in the soils and their abilities to withstand high temperatures,

\footnotetext{
* Corresponding author.

E-mail addresses: welch.318@osu.edu (S.A. Welch), mashkour@mnhn.fr (M. Mashkour).
} 
Table 1

Sample locations and descriptions.

\begin{tabular}{|c|c|c|}
\hline \multicolumn{3}{|c|}{ Water Samples } \\
\hline Sample ID & Location & Description \\
\hline St 10 & $\begin{array}{l}\text { Lat } 29^{\circ} 34.831^{\prime} \mathrm{N} \text { Long } 58^{\circ} \\
58.428^{\prime} \mathrm{E}\end{array}$ & Sample obtained by digging into the sand dune at the depth of $80 \mathrm{~cm}$ below the land surface (Ab-e Yalan). \\
\hline St 19 & $\begin{array}{l}\text { Lat } 29^{\circ} 48.780^{\prime} \text { NLong } 59^{\circ} \\
11.675^{\prime} \mathrm{E}\end{array}$ & $\begin{array}{l}\text { Location known as "Logger Point". No Sign of surface water but dug into a brownish soil and reached water @ } 90 \mathrm{~cm} \text { depth. } \\
\text { Image in Fig. S2. }\end{array}$ \\
\hline St 21 & $\begin{array}{l}\text { Lat } 30^{\circ} 04.394^{\prime} \text { NLong } 58^{\circ} \\
55.298^{\prime} \mathrm{E}\end{array}$ & Water off surface, flows for $\sim 200 \mathrm{~m}$ and recharges (Sarcheshmeh-e Shoor Gaz) \\
\hline St 22 & $\begin{array}{l}\text { Lat } 30^{\circ} 04.144^{\prime} \text { NLong } 58^{\circ} \\
56.153^{\prime} \mathrm{E}\end{array}$ & $\begin{array}{l}\text { Further downstream from \#21, a very flat playa surrounded by scarpments. Known as Shoor Gaz Hamoun where surface } \\
\text { discharge was sampled. }\end{array}$ \\
\hline St 28 & $\begin{array}{l}\text { Lat } 30^{\circ} 24.025^{\prime} \mathrm{N} \text { Long } 58^{\circ} \\
59.519^{\prime} \mathrm{E}\end{array}$ & Low lying playa, Chale Malek-Mohammad sampled water from swamp area. Image in Fig. S2. \\
\hline $\begin{array}{l}\text { Soil Sample } \\
\text { Sample ID }\end{array}$ & Location & Description \\
\hline 2 & Lat $30^{\circ} 58.20^{\prime} \mathrm{N}$ Long $5731.68^{\prime} \mathrm{E}$ & Small depression, $70 \mathrm{~km} \mathrm{~N}$ of Shahdad with sparse Hammada salicornica shrubs \\
\hline 5 & Lat $31^{\circ} 0.05^{\prime} \mathrm{N}$ Long $57^{\circ} 40.80^{\prime} \mathrm{E}$ & Near saline river, Rude Shoore Gadom Berian \\
\hline 8 & Lat $30^{\circ} 55.35^{\prime} \mathrm{N}$ Long $58^{\circ} 22.33^{\prime} \mathrm{E}$ & Mixture of Kalut soil profile and brown soil with some salt crystals near the Kal-e Lut \\
\hline 9 & Lat $30^{\circ} 53.90^{\prime} \mathrm{N}$ Long $58^{\circ} 23.88^{\prime} \mathrm{E}$ & Brown soil from Lut Playa \\
\hline 13 & Lat $30^{\circ} 34.82^{\prime} \mathrm{N}$ Long $58^{\circ} 35.62^{\prime} \mathrm{E}$ & Sand from Kalute Abul hol \\
\hline 18 & Lat $30^{\circ} 6.63^{\prime} \mathrm{N}$ Long $58^{\circ} 43.57^{\prime} \mathrm{E}$ & Dagh (playa) of the eastern corner of Kalutes, scattered Tamarix pycnocarpa and Suaeda fruticosa \\
\hline 20 & Lat $30^{\circ} 2.53^{\prime} \mathrm{N}$ Long $58^{\circ} 49.68^{\prime} \mathrm{E}$ & Sample from Shoorgaze Hamoun's puffy salt flat \\
\hline 25 & Lat $29^{\circ} 48.80^{\prime} \mathrm{N}$ Long $59^{\circ} 11.68^{\prime} \mathrm{E}$ & Location known as “2005 Logger Point”. Sample contains high moisture. \\
\hline 28 & Lat $29^{\circ} 45.58^{\prime} \mathrm{N}$ Long $59^{\circ} 3.11^{\prime} \mathrm{E}$ & Water runnel between Shoor Gaz and southern Lut, Seidlitzia rosmarinus, Tamarix kermanensis \\
\hline 33 & Lat $29^{\circ} 20.80^{\prime} \mathrm{N}$ Long $59^{\circ} 3.35^{\prime} \mathrm{E}$ & Mile Baluchena, Desmostachys bipinnata \\
\hline 37 & Lat $29^{\circ} 17.22^{\prime} \mathrm{N}$ Long $59^{\circ} 5.58^{\prime} \mathrm{E}$ & Surface sample from Shahrokh-Abad Plain, Seidlitzia Rosmarinus \\
\hline
\end{tabular}

Soil samples were taken from the top 10-cm of the soil profile and stored in plastic bags. Air-dried samples were passed through 2 mm sieve and diluted with distilled water following the method described by Bolukbasi et al. (2015). Soil conductivity and pH was measured using a pH/Conductivity meter (ORION STAR A215) by diluting samples with distilled water to 1:2.5 and 1:5, respectively. The percentage of gypsum content in the soil was determined gravimetrically by comparing samples dried at $60^{\circ} \mathrm{C}$ and $105^{\circ} \mathrm{C}$ (Porta et al., 1986). Total carbon $\left(\mathrm{C}_{\mathrm{t}}\right)$ was measured by elemental analyzer following the Dumas method (Elementar C/N; VarioMax, Hanau, Germany). All soil measurements were conducted at Instituto Pirenaico de Ecología (IPE-CSIC), Spain.

UV light, and even radiation (Mazkour et al., 2017; Mohseni et al., 2014; Shirsalimian et al., 2017). Although previous studies have described the unusual desert geomorphology (Yazdi et al., 2014), there has been little attempt to understand other surficial and shallow subsurface processes occurring there. In addition, the recent expeditions discovered a shallow subsurface water system in at least a portion of this extremely hot place (Stone, 2016; Trescher, 2017). As a first attempt to better understand the biodiversity and describe the physical environment of the Lut Desert, and as part of a large scientific program (Adaptation and Function of Lut Desert Biodiversity (AFLDB) project), we present the first geochemical data on these waters, speculate on their origin and evolution, and compare them to what is known about other hyper-arid environments in Israel, China, Chile, Australia and the western United States.

\section{Methods}

The sampling coordinates and depths are given in Table 1 , and sampling locations shown in Fig. 1. Surface water or shallow groundwater samples ( $\sim 1 \mathrm{~m}$ depth) were taken by hand in pre-cleaned $120 \mathrm{ml}$ widemouth LDPE bottles. In some cases, overlying sediment/soil was removed by shovel prior to sampling the water. The water samples were filtered through $0.4 \mu \mathrm{m}$ membrane filters using precleaned polycarbonate filtration system into a series of smaller precleaned LDPE bottles and stored in the dark at $\sim 4{ }^{\circ} \mathrm{C}$ until analysis. Major cations and anions were determined via ion chromatography after appropriate dilution with MilliQ ${ }^{\mathrm{TM}}$ water (Lyons et al., 2005; Welch et al., 2010). Li and $\mathrm{Sr}$ were measured by ICP-OES and $\mathrm{Ni}, \mathrm{Rb}, \mathrm{Ba}$ and $\mathrm{Pb}$ measured by ICP-MS on aliquots diluted such that the total dissolved salts (TDS)

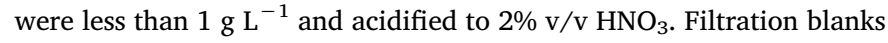
were also processed and analyzed as samples. Phosphate, $\mathrm{NO}_{3}{ }^{-}+\mathrm{NO}_{2}{ }^{-}, \mathrm{NH}_{4}{ }^{+}$and $\mathrm{H}_{4} \mathrm{SiO}_{4}$ were measured using a Skalar San + + nutrient analyzer. The bicarbonate concentration was determined by

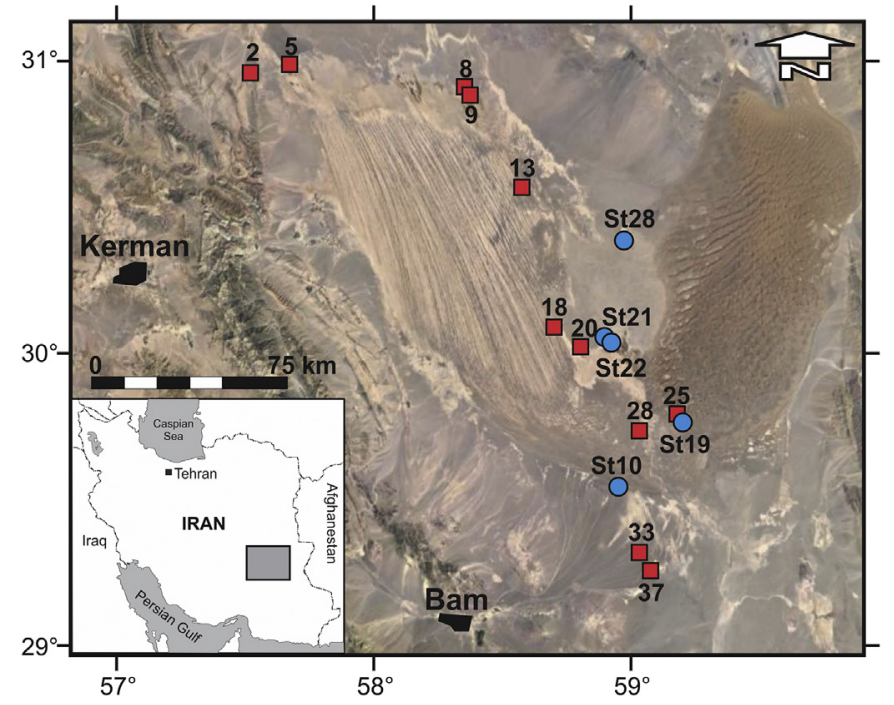

Fig. 1. Location of water (blue circles) and soil (red squares) sampling sites across the Lut Desert, east Iran. (For interpretation of the references to colour in this figure legend, the reader is referred to the Web version of this article.)

the difference in charge balance between the measured cations and anions (Lyons et al., 2012). The precision of all directly measured constituents was better than $10 \%$ (most were better than $5 \%$ ), based on replicate analysis of samples and standards (Welch et al., 2010). Our previous work suggests that $\mathrm{HCO}_{3}{ }^{-}$determined by charge balance difference are usually better than $\pm 14 \%$ (Lyons et al., 2012). Water isotope composition, $\delta \mathrm{D}$ and $\delta^{18} \mathrm{O}$, were determined using a Picarro water isotope analyzer (Carey et al., 2016). 
Table 2

Water chemistry for Lut Dessert samples.

\begin{tabular}{|c|c|c|c|c|c|c|}
\hline & $\mathrm{Cl}$ & $\mathrm{SO}_{4}$ & $\mathrm{NO}_{3} \mathrm{~N}$ & $\mathrm{Br}$ & F & $\mathrm{HCO}_{3}$ \\
\hline & $\mathrm{mM}$ & $\mathrm{mM}$ & $\mathrm{mM}$ & $\mathrm{mM}$ & $\mathrm{mM}$ & $\mathrm{mM}$ \\
\hline St 10 & 284 & 40.6 & 0.866 & 0.099 & 0.035 & 75.5 \\
\hline St 19 & 783 & 21.9 & 12.34 & 0.019 & na & 41.2 \\
\hline St 21 & 634 & 32.7 & 8.72 & 0.019 & na & 36.9 \\
\hline St 22 & 1874 & 28.9 & 30.85 & 0.027 & 0.032 & 263 \\
\hline \multirow[t]{2}{*}{ St 28} & 5373 & 5.3 & 82.83 & 0.052 & 0.119 & 66 \\
\hline & $\begin{array}{l}\mathrm{Na} \\
\mathrm{mM}\end{array}$ & $\begin{array}{l}\mathbf{K} \\
\mathrm{mM}\end{array}$ & $\begin{array}{l}\mathbf{M g} \\
\mathrm{mM}\end{array}$ & $\begin{array}{l}\mathrm{Ca} \\
\mathrm{mM}\end{array}$ & $\begin{array}{l}\mathrm{Li} \\
\mathrm{mM}\end{array}$ & $\begin{array}{l}\mathrm{Sr} \\
\mathrm{mM}\end{array}$ \\
\hline St 10 & 394 & 2.01 & 10.8 & 12.3 & 0.718 & 0.187 \\
\hline St 19 & 688 & 1.86 & 13.9 & 81.3 & 0.189 & 0.702 \\
\hline St 21 & 596 & 1.54 & 22.3 & 51.7 & 0.225 & 0.506 \\
\hline St 22 & 1910 & 6.77 & 65.3 & 94.5 & 0.647 & 1.11 \\
\hline \multirow[t]{2}{*}{ St 28} & 5250 & 8.86 & 89.3 & 353 & 2.18 & 3.27 \\
\hline & $\begin{array}{l}\mathrm{P} \mathrm{PO}_{4} \\
\mu \mathrm{M}\end{array}$ & $\begin{array}{l}\mathrm{N} \mathrm{NH}_{4} \\
\mu \mathrm{M}\end{array}$ & $\begin{array}{l}\mathrm{NO}_{2}+\mathrm{NO}_{3} \\
\mathrm{mM}\end{array}$ & $\begin{array}{l}\mathrm{Si} \\
\mu \mathrm{M}\end{array}$ & $\begin{array}{l}\delta^{18} \mathrm{O} \\
\% 0\end{array}$ & $\begin{array}{l}\delta \mathrm{D} \\
\% 0\end{array}$ \\
\hline St 10 & 1.58 & 8.54 & 1.13 & 340 & -3.35 & -19.96 \\
\hline St 19 & 0.53 & 21.4 & 12.3 & 282 & 5.64 & -14.16 \\
\hline St 21 & 0.33 & 24.5 & 9.00 & 262 & 4.46 & -14.65 \\
\hline St 22 & 1.04 & 46.0 & 35.1 & 279 & 6.35 & -9.11 \\
\hline St 28 & 2.56 & 97.5 & 81.5 & 169 & 17.86 & 26.91 \\
\hline \multirow[t]{2}{*}{ ICP MS } & $\mathrm{Ni}$ & $\mathrm{Rb}$ & $\mathrm{Ba}$ & $\mathrm{Pb}$ & & TDS \\
\hline & $\mu \mathrm{g} / \mathrm{l}$ & $\mu \mathrm{g} / 1$ & $\mu \mathrm{g} / 1$ & $\mu g / 1$ & & $\mathrm{~g} / \mathrm{kg}$ \\
\hline St 10 & 24.5 & 43.6 & 125 & 1.5 & & 27.9 \\
\hline St 19 & 112 & 46.4 & 139 & 1.0 & & 50.8 \\
\hline St 21 & 84.7 & 26.8 & 71.2 & 2.0 & & 43.4 \\
\hline St 22 & 150 & 79.6 & 141 & 5.4 & & 127.2 \\
\hline St 28 & 520 & 134 & 826 & 23.0 & & 281.2 \\
\hline
\end{tabular}

\section{Results and Discussion}

The water geochemistry data and soil chemical parameters are shown in Tables 2 and 3, respectively. A number of general observations of these data can be made. All the waters are $\mathrm{Na}-\mathrm{Cl}$, but they are unlike seawater derived brines in that $\mathrm{Ca}^{2+}>\mathrm{Mg}^{2+}$ and $\mathrm{HCO}_{3}{ }^{-}>\mathrm{SO}_{4}{ }^{2-}$ (Fig. 2). The $\mathrm{K}$ concentrations are uniformly low relative to $\mathrm{Na}$. Unlike some hypersaline waters in extremely hyper arid environments, the $\mathrm{Li}, \mathrm{Mg}$, and $\mathrm{Br}$ concentrations are relatively low (Long et al., 1992; Lyons and Welch, 1997; Vengosh, 2013). In fact, the increasing $\mathrm{Cl}: \mathrm{Br}$ ratios with increasing $\mathrm{Cl}^{-}$suggest extensive halite dissolution has helped increase the $\mathrm{Cl}$ concentration relative to $\mathrm{Br}$ in these waters (Fig. 3) (McCaffrey et al., 1987). With the possible exception of sample 10 , the N:P ratios are extremely high, $\sim 20,000$ to 30,000:1, much higher than found in most natural waters (Berner and

Table 3

Chemical properties of soil samples from Lut Desert.

\begin{tabular}{lllll}
\hline Sample ID & $\mathrm{pH}$ & $\mathrm{EC} \mu \mathrm{S} / \mathrm{cm}$ & $\mathrm{C}_{\mathrm{t}} \%$ & GypsumWt \% \\
\hline 2 & 9.12 & 859 & 0.95 & 8.92 \\
5 & 8.57 & 836 & 1.16 & 17.59 \\
8 & 7.92 & 4481 & 0.89 & 60.68 \\
9 & 7.96 & 5780 & 1.12 & 71.00 \\
13 & 9.18 & 1160 & 0.33 & 2.75 \\
18 & 8.62 & 370 & 1.58 & 6.01 \\
20 & 8.28 & 9210 & 1.05 & 50.79 \\
25 & 8.89 & 1513 & 0.86 & 8.57 \\
28 & 9.10 & 560 & 1.67 & 5.50 \\
33 & 8.91 & 1298 & 1.92 & 7.43 \\
37 & 7.59 & 2884 & 1.74 & 41.17 \\
\hline
\end{tabular}

Berner, 2012; Schlesinger and Bernhardt, 2013). These high concentrations of $\mathrm{NO}_{3}{ }^{-}+\mathrm{NO}_{2}{ }^{-}$indicate the accumulation of $\mathrm{NO}_{3}{ }^{-}$ within the landscape, minimal biological uptake of $\mathrm{N}$, and the lack of extensive denitrification within the shallow groundwater (Fig. 3).

The accumulation of soluble salts in a landscape occurs when evaporation exceeds precipitation and there is little to no flushing of the salts. Shallow saline groundwater can develop from a combination of two important processes: by meteoric waters being evaporated, hence concentrating the solutes along its flow path, and by the dissolution of previously accumulated salts. The former process can be traced by a change in water isotope signals (i.e. $\delta \mathrm{D}$ and $\delta^{18} \mathrm{O}$ ) with salinity, while the latter through the observance of an increase in the ratios of certain solutes such as $\mathrm{Cl}: \mathrm{Br}$ with salinity (Vengosh, 2013). As noted above and seen in Table 2, the $\mathrm{Cl}: \mathrm{Br}$ of these waters increase with $\mathrm{Cl}^{-}$(Fig. 3), suggesting strongly that the dissolution of previously deposited halite is a major control on the overall salinity of these waters. This appears to be particularly the case in the three most saline samples where the $\mathrm{Cl}$ :Na ratio is $\sim 1$ (Table 2, Fig. 3). This same phenomenon has been observed in other parts of Iran (Jalali, 2007; Nassery and Kayhomayoon, 2013).

We used the Pitzer database in PHREEQC (US Geological Survey, v 3.4.0, Parkhurst and Appelo, 2013) to calculate the saturation state of a number of common binary salts in these brines (Table 4). We were unable to measure $\mathrm{pH}$ in the field, so we have done these calculations using both $\mathrm{pH} 7$ and 8, although only the $\mathrm{CaCO}_{3}$ polymorphs and dolomite are greatly affected by the $\mathrm{pH}$ variations. The $\mathrm{pH}$ of the soil slurry measurements were all slightly alkaline (Table 3) with $\mathrm{pH}$ ranging from 7.59 to 9.18 , thus only the modelling results for $\mathrm{pH} 8$ are presented in Table 4. Calculations were also done at 25,50 and $70{ }^{\circ} \mathrm{C}$ to estimate mineral saturation index (SI) over the range of temperatures expected in the field (Alavipanah et al., 2007; Rahimzadeh et al., 2009). The carbonate minerals were supersaturated in all the samples with greater saturation indices for samples with higher salinities (Tables 3 and 4). The saturation index for carbonate minerals increased with temperature due to their retrograde solubility, suggesting that increased temperature, as well as increased evaporation, should induce carbonate mineral precipitation from these saline brines. All waters were at, or very near, equilibrium with respect to gypsum and anhydrite (SI ranging from -0.64 to 0.34 ) with values generally increasing with increasing salinity. The calculated SI values decrease with temperature for gypsum, but increase for anhydrite, suggesting that the extreme temperatures in this environment favors the formation of anhydrite over gypsum. Most waters were also slightly supersaturated or very near equilibrium with respect to barite at $25{ }^{\circ} \mathrm{C}$, except for the most saline water (sample 28), which was slightly undersaturated. Though saturation index decreases with increasing temperatures, suggesting that barite precipitates could start dissolving in the brines at in situ conditions. With the exception of sample 10, most of the brines were slightly supersaturated with respect to celestite $\left(\mathrm{SrSO}_{4}\right)$, and like barite, SI decreases with increasing temperature, suggesting that the temperature variations described in this environment could be important controls for the solubility of $\mathrm{Ca}, \mathrm{Sr}, \mathrm{Ba}$, and $\mathrm{SO}_{4}$ in these shallow brines. The soil data from the top $10 \mathrm{~cm}$ support these calculations in that the abundant total soil carbon content $\left(\mathrm{C}_{\text {Total }}\right)$ values range from $\sim 1$ to $2 \%$ suggesting significant amounts of $\mathrm{CaCO}_{3}$. The gypsum concentrations are also very high but quite variable, with values between 2.75 and $71 \%$ of the total soil mass (Table 3$)$. There is a correlation $\left(\mathrm{R}^{2}=0.68\right)$ between gypsum content of soil and EC suggesting evaporation has played a major role in chemical evolution of both soil and brine in the Lut Desert (Figs. 3 and 4, Fig. S3). Most of the waters were slightly undersaturated with respect to amorphous $\mathrm{SiO}_{2}$. Halite is undersaturated except in the most saline brine sample (Sample 28). These calculations, along with the soil data suggest that the precipitation of gypsum $\left(\mathrm{CaSO}_{4} \cdot 2 \mathrm{H}_{2} \mathrm{O}\right)$ or anhydrite $\left(\mathrm{CaSO}_{4}\right)$, and the dissolution of previously deposited $\mathrm{NaCl}$, are major controls on the $\mathrm{Na}^{+}, \mathrm{Ca}^{2+}, \mathrm{SO}_{4}{ }^{2-}$ and $\mathrm{Cl}^{-}$concentration in these waters and that the upper limit of the 


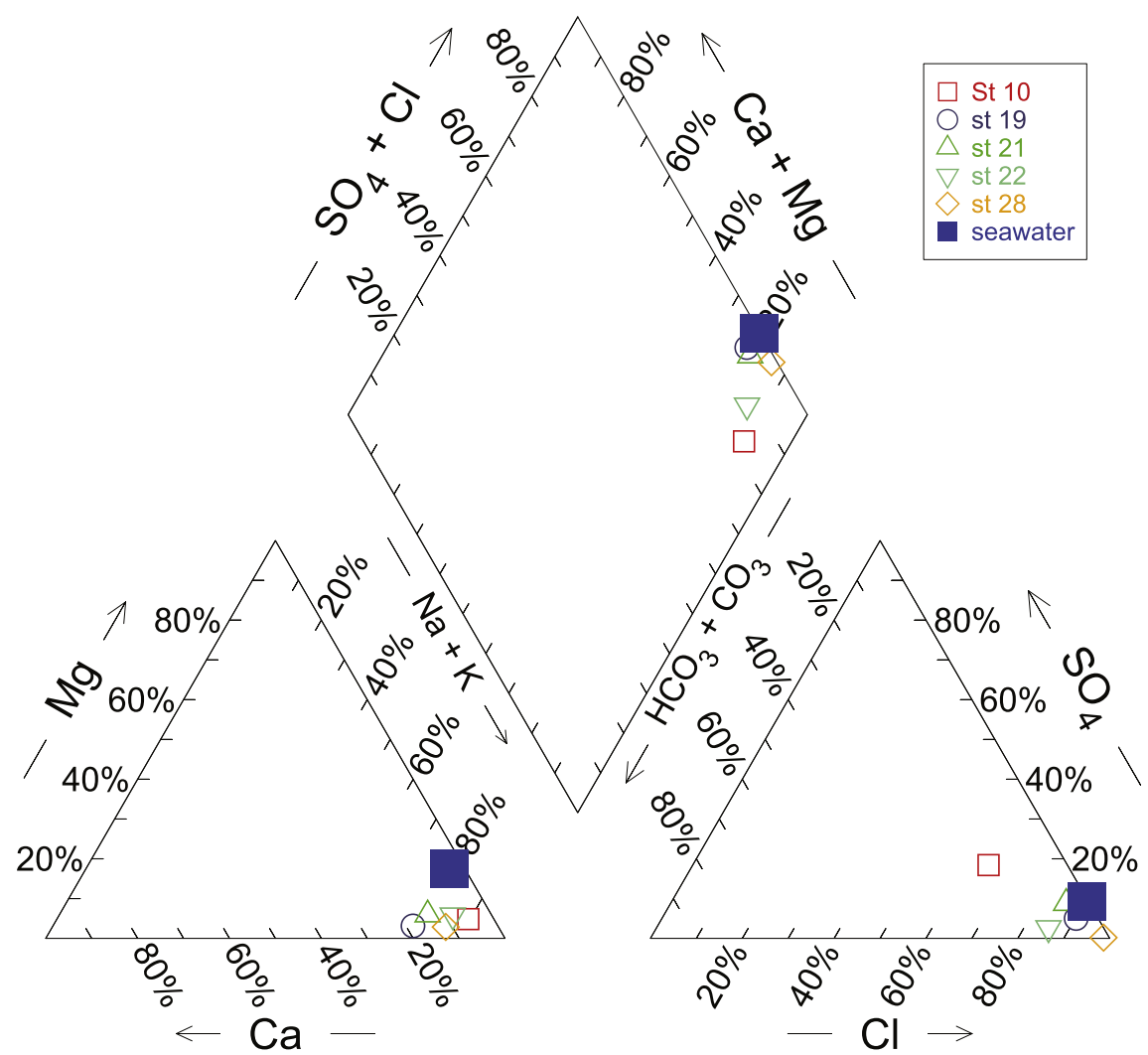

Fig. 2. Piper diagram of water samples collected from the Lut Dessert, with seawater plotted for comparison. Lut Dessert shallow groundwaters are all Na-Cl brines. Seawater data from Pilson (2012).

$\mathrm{H}_{4} \mathrm{SiO}_{4}$ is probably controlled by amorphous $\mathrm{SiO}_{2}$ precipitation. The latter hypothesis is also supported by the decrease of $\mathrm{Si}: \mathrm{Cl}$ with increasing $\mathrm{Cl}$ concentration (Fig. 2), which indicates that $\mathrm{Si}$ is not behaving conservatively as the brine is concentrating. The low $\mathrm{K}$ concentrations and the high Ca:Mg ratios may suggest that $\mathrm{K}^{+}$and $\mathrm{Mg}^{2+}$ concentrations are controlled by either adsorption of $\mathrm{K}$ and $\mathrm{Mg}$ onto silicate minerals, or authigenic clay mineral formation. Similar $\mathrm{K}$ loss has been observed along the flow path of shallow groundwaters in
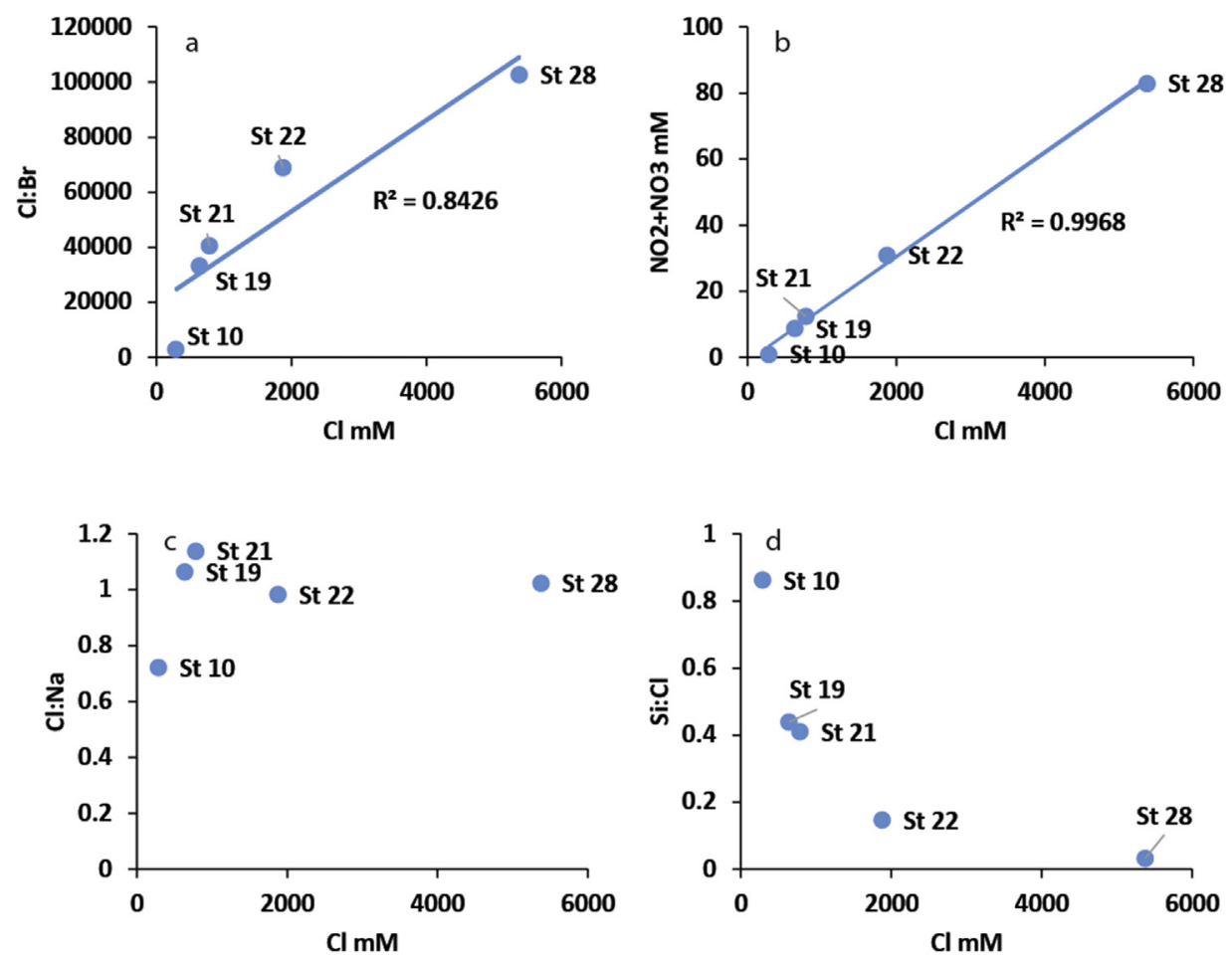

Fig. 3. Major ion ratio plots for water samples from the Lut Desert. a) $\mathrm{Cl}: \mathrm{Br}$ vs $\mathrm{Cl}$, b) $\mathrm{NO} 3+\mathrm{NO} 2$ vs $\mathrm{Cl}$, c) $\mathrm{Cl}: \mathrm{Na}$ vs $\mathrm{Cl}$ and d) $\mathrm{Si}: \mathrm{Cl}$ vs $\mathrm{Cl}$. 
Table 4

Saturation Indices of common binary salts calculated at 25,50 and $70{ }^{\circ} \mathrm{C}$ and pH 8 for Lut Desert water samples.

\begin{tabular}{|c|c|c|c|c|c|}
\hline Mineral & St 10 & St 19 & St 20 & St 21 & St 28 \\
\hline \multicolumn{6}{|l|}{$\mathrm{pH} 825^{\circ} \mathrm{C}$} \\
\hline Anhydrite & -0.64 & -0.31 & -0.28 & -0.23 & 0.26 \\
\hline Gypsum & -0.3 & 0.01 & 0.05 & 0.05 & 0.2 \\
\hline Barite & 0.66 & 0.25 & 0.18 & 0.1 & -0.56 \\
\hline Celestite & -0.15 & -0.03 & 0.06 & 0.02 & 0.5 \\
\hline Aragonite & 2 & 2.58 & 2.31 & 3.58 & 4.29 \\
\hline Calcite & 2.28 & 2.87 & 2.59 & 3.87 & 4.57 \\
\hline Dolomite & 4.55 & 5.05 & 4.91 & 7.55 & 8.79 \\
\hline Halite & -2.86 & -2.17 & -2.33 & -1.24 & 0.57 \\
\hline $\begin{array}{l}\mathrm{SiO}_{2} \text { (a) } \\
\text { pH } 850^{\circ} \mathrm{C}\end{array}$ & -0.77 & -0.8 & -0.85 & -0.65 & -0.19 \\
\hline Anhydrite & -0.36 & -0.04 & -0.01 & 0.05 & 0.32 \\
\hline Gypsum & -0.31 & 0 & 0.04 & 0.04 & 0 \\
\hline Barite & 0.41 & -0.03 & -0.08 & -0.19 & -0.87 \\
\hline Celestite & -0.06 & 0.05 & 0.15 & 0.13 & 0.48 \\
\hline Aragonite & 2.27 & 2.84 & 2.57 & 3.79 & 4.39 \\
\hline Calcite & 2.6 & 3.18 & 2.9 & 4.13 & 4.72 \\
\hline Dolomite & 5.22 & 5.69 & 5.55 & 8.06 & 9.06 \\
\hline Halite & -2.9 & -2.21 & -2.37 & -1.27 & 0.48 \\
\hline $\begin{array}{l}\mathrm{SiO}_{2}(\mathrm{a}) \\
\mathrm{pH} 870^{\circ} \mathrm{C}\end{array}$ & -0.99 & -1.03 & -1.07 & -0.89 & -0.59 \\
\hline Anhydrite & -0.14 & 0.17 & 0.21 & 0.25 & 0.34 \\
\hline Gypsum & -0.28 & 0.01 & 0.05 & 0.04 & -0.17 \\
\hline Barite & 0.25 & -0.21 & -0.26 & -0.4 & -1.09 \\
\hline Celestite & 0 & 0.1 & 0.2 & 0.17 & 0.43 \\
\hline Aragonite & 2.46 & 3.02 & 2.75 & 3.95 & 4.48 \\
\hline Calcite & 2.8 & 3.37 & 3.09 & 4.29 & 4.83 \\
\hline Dolomite & 5.53 & 5.99 & 5.85 & 8.28 & 9.14 \\
\hline Halite & -2.92 & -2.23 & -2.39 & -1.28 & 0.41 \\
\hline $\mathrm{SiO}_{2}(\mathrm{a})$ & -1.14 & -1.18 & -1.23 & -1.07 & -0.87 \\
\hline
\end{tabular}

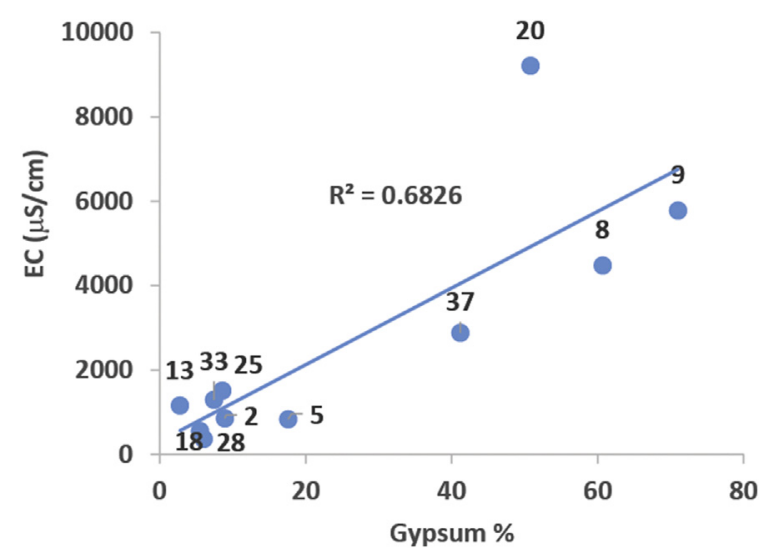

Fig. 4. The correlation between soil's electrical conductivity $\left(\mu \mathrm{S} \mathrm{cm}^{-1}\right)$ and gypsum content (\%) in soil samples from Lut Desert. the Atacama Desert (Magaritz et al., 1989). Except for sample 10, the $\mathrm{Ca} / \mathrm{Sr}$ ratios are very similar to seawater (mean $\mathrm{Ca} / \mathrm{Sr} 103$ compared to seawater $\mathrm{Ca} / \mathrm{Sr}$ of 113). Sample 10 more closely reflects the crustal ratio (of 66), indicating along with the highest $\mathrm{H}_{4} \mathrm{SiO}_{4}$ that this water reflects a chemical weathering component that becomes less significant at higher salinities. The concentrations of most trace elements detected ( $\mathrm{Li}, \mathrm{Ni}, \mathrm{Rb}, \mathrm{Ba}, \mathrm{Sr}, \mathrm{Pb}$, as well as $\mathrm{NH}_{4}{ }^{+}$) generally correlate with salinity of the brines. The wetting and drying cycles are important in this system as demonstrated by both the very high $\mathrm{Cl}: \mathrm{Br}$ ratios, and the mineral saturation calculations, which, as noted above, indicate that the dissolution of previously deposited $\mathrm{NaCl}$ is a very significant process. Drever and Smith (1978) have demonstrated that cyclic wetting and drying in arid climates can lead to brines depleted in $\mathrm{SO}_{4}{ }^{2-}, \mathrm{Mg}^{2+}$ and $\mathrm{Si}$ relative to $\mathrm{Cl}^{-}$, similar to what we observe in these waters. This is due to the kinetics of dissolution of previously deposited salts with the most soluble salts redissolving more readily than the less soluble salts.

The stable isotopes of water are shown in Table 2 and plotted in Fig. 5A. The global meteoric water line as well as the local meteoric water lines (LMWL) for Tehran and snowmelt from the Zagros Mountains to the north and west of the Lut Desert are plotted for comparison (Mosaffa et al., 2015; Osati et al., 2014). The least saline sample (10) plots closest to the meteoric lines and is also similar to the modeled "isoscapes" precipitation value for this general region (Bowen and Revenaugh, 2003). Samples 21, 19 and 22 plot obliquely to the LMWLs (Fig. 5A) suggesting extensive evaporation, while sample 28, the most saline water, plots very far off the lines indicating massive evaporative loss. These data coupled with the $\mathrm{Cl}: \mathrm{Br}$ values strongly indicate that both extensive evaporation and salt dissolution have played a role in producing these hypersaline waters.

Spatial distribution patterns of $\delta^{18} \mathrm{O}$ and $\delta \mathrm{D}$ values show significant depletion from station 28 to station 10 (Fig. 6, Fig. S4), where a one degree equatorward shift causes around 21 and $48 \%$ depletion in $\delta^{18} \mathrm{O}$ and $\delta \mathrm{D}$ values, respectively. The observed gradients in isotopic values of Lut water samples are too high to be explained by the latitude effect (e.g. Bershaw et al., 2012; Bowen and Wilkinson, 2002). The effect of altitude as well as the amount of precipitation (altitude and amount effects) cannot explain such a shift either, due to very low annual precipitation and low elevation gradient in Lut desert. A strong correlation $\left(\mathrm{R}^{2}=0.8\right)$ is observed in changes in $\delta^{18} \mathrm{O}$ values with respect to total dissolved solid (TDS), Fig. 5B. This observation supports the idea that a high gradient shift in $\delta^{18} \mathrm{O}$ and $\delta \mathrm{D}$ values are related to the salinity of waters caused by evaporation processes (Conroy et al., 2014).

\subsection{Implications for other hyper-arid environments}

We have reviewed the available data from a number of other hyperarid regions, and the geochemistry of the soils/shallow groundwaters have great similarities. Shallow groundwaters in Death Valley/Mojave

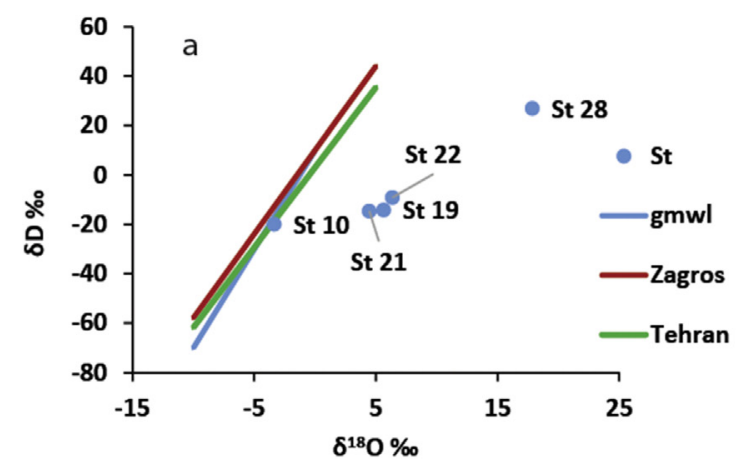

Fig. 5. A) Isotope data plots and $5 \mathrm{~B}$ ) the $\delta^{18} \mathrm{O}$-TDS relationship for Lut Desert water samples. 


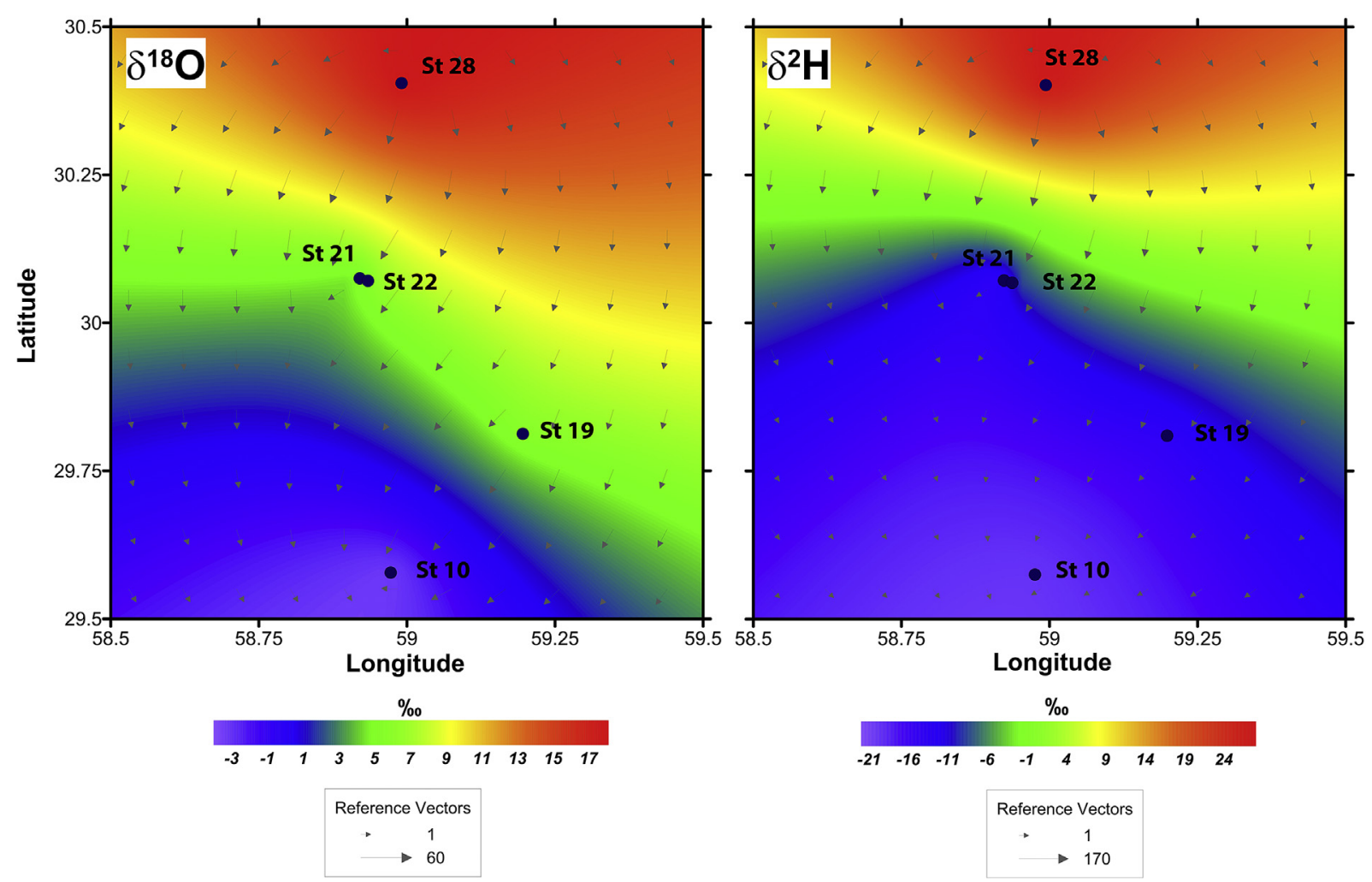

Fig. 6. Gradient of $\delta^{18} \mathrm{O}$ (left) and $\delta^{2} \mathrm{H}$ (right) in the Lut Desert. Arrows denote gradient vectors.

Desert, USA, the Atacama, Chile, and the Turpan Basin, NW China have high TDS, and are primarily $\mathrm{Na}-\mathrm{Cl}$ waters, although some $\mathrm{Na}-\mathrm{SO}_{4}$ waters also exist (Boutt et al., 2016; Chen et al., 2014; Thomas et al., 1996). These waters are evapoconcentrated meteoric waters that have also solubilized previously deposited evaporite minerals, such as gypsum, mirabilite and halite (Chen et al., 2014; Magaritz et al., 1989; Thomas et al., 1996). All of this information indicates that periodic wetting and the precipitation/dissolution cycling of soluble salts play a very important role in controlling the geochemistry of all these waters. The vadose zones of these environments, as well as the shallow groundwaters, can accumulate large amounts of very soluble ions, such as nitrate (Finstad et al., 2016; Lybrand et al., 2013; Qin et al., 2012). High $\mathrm{NO}_{3}{ }^{-}+\mathrm{NO}_{2}{ }^{-}$concentrations in groundwater are observed in other hyper-saline systems such as the Negev Desert, and Central Australia (Barnes et al., 1992; Rosenthal et al., 1987). This $\mathrm{NO}_{3}{ }^{-}$is presumably deposited from the atmosphere and accumulates over time (Böhlke et al., 1997; Lyons et al., 2016) or was initially fixed biologically, oxidized and flushed from the unsaturated zone (Barnes et al., 1992; Rosenthal et al., 1987). Associated with the nitrate can be both perchlorate and iodate salts (Lybrand et al., 2016). We have observed another unidentified peak in the anion chromatograms which falls where the perchlorate anion would generally be seen. Perchlorate has been observed in other hyperarid regions in the world, including the Atacama and the McMurdo Dry Valleys of Antarctica (Ericksen, 1981; Jackson et al., 2015, 2012). In all these environments a high percentage of this nitrate originates from the atmosphere, suggesting, like in the Lut Desert, the role of biological processes in controlling $\mathrm{N}$ distribution is probably minor. Our data from the Lut, when compared to these other settings, suggest that the processes that control the geochemistry of these surficial and shallow subsurface environments are similar. The abundance of $\mathrm{NO}_{3}{ }^{-}$, and the potential presence of perchlorate, suggests little biological alteration of these very soluble salts.

The accumulation of these salts in soils and shallow groundwaters and the partitioning between the two are related to the stability of the landscape, the climate, and the landscape age, as previously noted by
Lybrand et al. (2016). Additions of water clearly can remove salts from the soils solubilizing and transporting them into the shallow groundwaters. Conversely, extensive hyper-aridity can lead to the precipitation of salts. Cation exchange and possibly authigenic aluminosilicate mineral formation in the shallow groundwaters can influence $\mathrm{K}$ concentrations, as we have observed in the Lut and others have observed in desert waters (Magaritz et al., 1989), as well as influence both the vertical and horizontal distribution of soluble binary salts in soils (Boutt et al., 2016; Finstad et al., 2016; Lybrand et al., 2013). The lack of halite saturation may also suggest that the basin is not hydrologically closed and water is being lost at depth through leakage as outlined in Wood and Sanford (1990) and Rosen (1994), as non-evaporative groundwater loss can result in steady state solute concentrations that do not approach more soluble salt deposition (Wood and Sanford, 1990). As noted above, the Lut Block is highly faulted, and tectonic controls on groundwater geochemistry in Iran have previously been noted (Masoodi and Rahimzadeh, 2018).

\section{Conclusions}

We present, to our knowledge, the first geochemical analysis of water from one of the hottest locations on the Earth, the Lut Desert, Iran. The data indicate that the salinity of these waters is produced by both evaporative processes and dissolution of previously deposited salts, and thus wetting and drying are very important factors in controlling brine geochemical evolution. Thermodynamic calculations indicate that waters are essentially in equilibrium with gypsum and are also highly supersaturated with respect to carbonate minerals. Chemical weathering of aluminosilicate minerals, in what we assume to be the fresher regions of the flow systems, produce high $\mathrm{H}_{4} \mathrm{SiO}_{4}$ concentrations that may be later controlled by equilibrium with amorphous $\mathrm{SiO}_{2}$ precipitation as water is lost and brine becomes more saline. Soluble ions such as $\mathrm{NO}_{3}{ }^{-}$are found at very high concentrations in these waters suggesting little to no removal via biological processes. However other soluble ions that sometimes accumulate in hypersaline 
environments are not evapoconcentrated to a great extent. The data presented within adds important new information on the geochemical evolution of hyper-arid environments from a system heretofore undescribed.

\section{Acknowledgements}

We are grateful to Ms Devin Smith for helping with water isotope measurements. The material for this contribution was available under the Adaptation and Function of Lut Desert Biodiversity (AFLDB) project, coordinated by the SAEEDI Institute for Advanced Studies (SIAS), University of Kashan and University of Tehran. The field project was partially funded by the LIA-HAOMA CNRS, France. We thank Mr. Bahman Izadi and the logistic team for their great effort during the field work. This study was supported by project CGL2015-71360-P (Ministerio de Economía, Industria y Competitividad, Spain) to SP, and project i-COOPB20231 (Consejo Superior de Investigaciones Científicas, Spain) to SP and ZM. SP was funded by Ramón y Cajal contract (RYC-2013-14164, Ministerio de Ciencia, Innovación y Universidades, Spain). We would like to thank the editors, Dr. MuñozRojas and Dr. Damian Ravetta, and the anonymous reviewers whose thoughtful comments improved our manuscript.

\section{Appendix A. Supplementary data}

Supplementary data to this article can be found online at https:// doi.org/10.1016/j.jaridenv.2020.104143.

\section{References}

Alavipanah, S.K., Saradjian, M., Savaghebi, G.R., Komaki, C.B., Moghimi, E., Reyhan, M.K., 2007. Land surface temperature in the yardang region of Lut desert (Iran) based on field measurements and landsat thermal data. J. Agric. Sci. Technol. 9, 287-303.

Arjmandzadeh, R., Santos, J.F., 2014. Sr-Nd isotope geochemistry and tectonomagmatic setting of the Dehsalm Cu-Mo porphyry mineralizing intrusives from Lut Block, eastern Iran. Int. J. Earth Sci. 103, 123-140. https://doi.org/10.1007/s00531-0130959-4.

Azizi, G., Kazem, S., Panah, A., Goodarzi, N., Storm, D., Advisory, W., 2007. An estimation of the temperature of Lut desert using MODIS sensor data Archive of SID an estimation of the temperature of Lut desert using MODIS sensor data. Biaban 12, $7-16$.

Barnes, C.J., Jacobson, G., Smith, G.D., 1992. The origin of high-nitrate ground waters in the Australian arid zone. J. Hydrol. 137, 181-197. https://doi.org/10.1016/00221694(92) $90055-Z$.

Berner, E.K., Berner, R.A., 2012. Global Environment Water, Air, and Geochemical Cycles, second ed. Princeton University Press.

Bershaw, J., Penny, S.M., Garzione, C.N., 2012. Stable isotopes of modern water across the Himalaya and eastern Tibetan Plateau: implications for estimates of paleoelevation and paleoclimate. J. Geophys. Res. Atmos. 117, 1-18. https://doi.org/10.1029/ 2011JD016132.

Böhlke, J.K., Ericksen, G.E., Revesz, K., 1997. Stable isotope evidence for an atmospheric origin of desert nitrate deposits in northern Chile and southern California. U.S.A. Chem. Geol. 136, 135-152. https://doi.org/10.1016/S0009-2541(96)00124-6.

Bolukbasi, A., Kurt, L., Palacio, S., 2015. Unravelling the mechanisms for plant survival on gypsum soils: an analysis of the chemical composition of gypsum plants from Turkey. Plant Biol. 18, 271-279. https://doi.org/10.1111/plb.12401.

Boshrabadi, A.R., Khatib, M.M., Raeesi, M., Mousavi, S.M., Djamour, Y., 2018. Geometrickinematic characteristics of the main faults in the W-SW of the Lut Block (SE Iran). J. Afr. Earth Sci. 139, 440-462. https://doi.org/10.1016/j.jafrearsci.2017.12.027.

Boutt, D.F., Hynek, S.A., Munk, L.A., Corenthal, L.G., 2016. Rapid recharge of fresh water to the halite-hosted brine aquifer of Salar de Atacama, Chile. Hydrol. Process. 30, 4720-4740. https://doi.org/10.1002/hyp.10994.

Bowen, G.J., Revenaugh, J., 2003. Interpolating the isotopic composition of modern meteoric precipitation. Water Resour. Res. 39, 1-13. https://doi.org/10.1029/ 2003WR002086.

Bowen, G.J., Wilkinson, B., 2002. Spatial distribution of 8180 in meteoric precipitation. Geology 30, 315-318. https://doi.org/10.1130/0091-7613(2002)030<0315.

Carey, A.E., Welch, S.A., Lyons, W.B., 2016. Urban dust and central Ohio precipitation 3. pp. 31-37. https://doi.org/10.14644/dust.2016.005.

Chen, X., Wang, W.F., Luo, G.P., Ye, H., 2014. Can soil respiration estimate neglect the contribution of abiotic exchange? J. Arid Land 6, 129-135. https://doi.org/10.1007/ s40333-013-0244-1.

Conroy, J.L., Cobb, K.M., Lynch-Stieglitz, J., Polissar, P.J., 2014. Constraints on the salinity-oxygen isotope relationship in the central tropical Pacific Ocean. Mar. Chem. 161, 26-33. https://doi.org/10.1016/j.marchem.2014.02.001.

Djamali, M., Akhani, H., Khoshravesh, R., Andrieu-Ponel, V., Ponel, P., Brewer, S., 2011.
Application de la Classification Bioclimatique Globale en Iran: implications pour comprendre la végétation actuelle et la biogéographie. Ecol. Mediterr. Rev. Int. d'écologie méditerranéenne = Int. J. Mediterr. Ecol. 37, 91-114.

Drever, J.I., Smith, C.L., 1978. Cyclic wetting and drying of the soil zone as an influence on the chemistry of groundwater in arid terrains. Am. J. Sci. https://doi.org/10. 2475/ajs.278.10.1448.

Ehsani, A.H., 2011. Geomorphometry of Lut mega-yardangs. Phys. Geogr. Res. Q. 42, 63-77.

Ericksen, G.E., 1981. Geology and origin of the Chilean nitrate deposits. Geol. Surv. Prof. Pap. 42. https://doi.org/10.2113/gsecongeo.15.3.187.

Finstad, K., Pfeiffer, M., McNicol, G., Barnes, J., Demergasso, C., Chong, G., Amundson, R., 2016. Rates and geochemical processes of soil and salt crust formation in Salars of the Atacama Desert, Chile. Geoderma 284, 57-72. https://doi.org/10.1016/j. geoderma.2016.08.020.

Jackson, W.A., Böhlke, J.K., Andraski, B.J., Fahlquist, L., Bexfield, L., Eckardt, F.D., Gates, J.B., Davila, A.F., McKay, C.P., Rao, B., Sevanthi, R., Rajagopalan, S., Estrada, N., Sturchio, N., Hatzinger, P.B., Anderson, T.A., Orris, G., Betancourt, J., Stonestrom, D. Latorre, C., Li, Y., Harvey, G.J., 2015. Global patterns and environmental controls of perchlorate and nitrate co-occurrence in arid and semi-arid environments. Geochem. Cosmochim. Acta 164, 502-522. https://doi.org/10.1016/j.gca.2015.05.016.

Jackson, W.A., Davila, A.F., Estrada, N., Berry Lyons, W., Coates, J.D., Priscu, J.C., 2012. Perchlorate and chlorate biogeochemistry in ice-covered lakes of the McMurdo Dry Valleys, Antarctica. Geochem. Cosmochim. Acta 98, 19-30. https://doi.org/10.1016/ j.gca.2012.09.014.

Jalali, M., 2007. Salinization of groundwater in arid and semi-arid zones: an example from Tajarak, western Iran. Environ. Geol. 52, 1133-1149. https://doi.org/10.1007/ s00254-006-0551-3.

Long, D.T., Fegan, N.E., Lyons, W.B., Hines, M.E., Macumber, P.G., Giblin, A.M., 1992. Geochemistry of acid brines: lake tyrrell, victoria, Australia. Chem. Geol. 96, 33-52. https://doi.org/10.1016/0009-2541(92)90120-T.

Lybrand, R.A., Bockheim, J.G., Ge, W., Graham, R.C., Hlohowskyj, S.R., Michalski, G., Prellwitz, J.S., Rech, J.A., Wang, F., Parker, D.R., 2016. Nitrate, perchlorate, and iodate co-occur in coastal and inland deserts on Earth. Chem. Geol. 442, 174-186. https://doi.org/10.1016/j.chemgeo.2016.05.023.

Lybrand, R.A., Michalski, G., Graham, R.C., Parker, D.R., 2013. The geochemical associations of nitrate and naturally formed perchlorate in the Mojave Desert, California, USA. Geochem. Cosmochim. Acta 104, 136-147. https://doi.org/10.1016/j.gca. 2012.10.028.

Lyons, W.B., Deuerling, K., Welch, K.A., Welch, S.A., Michalski, G., Walters, W.W., Nielsen, U., Wall, D.H., Hogg, I., Adams, B.J., 2016. The soil geochemistry in the beardmore glacier region, Antarctica: implications for terrestrial ecosystem history. Sci. Rep. 6, 1-9. https://doi.org/10.1038/srep26189.

Lyons, W.B., Welch, K.A., 1997. Lithium in waters of a polar desert. Geochem. Cosmochim. Acta 61, 4309-4319. https://doi.org/10.1016/S0016-7037(97) 00203-2.

Lyons, W.B., Welch, K.A., Gardner, C.B., Jaros, C., Moorhead, D.L., Knoepfle, J.L., Doran, P.T., 2012. The geochemistry of upland ponds, Taylor Valley, Antarctica. Antarct. Sci. 24, 3-14. https://doi.org/10.1017/S0954102011000617.

Lyons, W.B., Welch, K.A., Snyder, G., Olesik, J., Graham, E.Y., Marion, G.M., Poreda, R.J., 2005. Halogen geochemistry of the McMurdo dry valleys lakes, Antarctica: clues to the origin of solutes and lake evolution. Geochem. Cosmochim. Acta 69, 305-323. https://doi.org/10.1016/j.gca.2004.06.040.

Magaritz, M., Aravena, R., Peña, H., Suzuki, O., Grilli, A., 1989. Water chemistry and isotope study of streams and springs in northern Chile. J. Hydrol. 108, 323-341. https://doi.org/10.1016/0022-1694(89)90292-8.

Masoodi, M., Rahimzadeh, M., 2018. Tectonic controls on groundwater geochemistry in Hormozgan Province, southern Iran. Arab. J. Geosci. 11, 1-9. https://doi.org/10. 1007/s12517-018-3478-6.

Mazkour, S., Hosseinzadeh, S., Shekarforoush, S., 2017. Evidence of heat-resistant microorganisms with a special emphasis on filamentous Actinomycetes in hyper-arid soils of Gandom Beryan area, Lut Desert, Iran. Iran. J. Microbiol. 9, 331-337.

McCaffrey, M.A., Lazar, B., Holland, H.D., 1987. The evaporation path of seawater and the coprecipitation of Br- and K+ with halite. SEPM J. Sediment. Res. 57, 928-937. https://doi.org/10.1306/212f8cab-2b24-11d7-8648000102c1865d.

Mildrexler, D.J., Zhao, M., Running, S.W., 2006. Where are the hottest spots on Earth? Eos 87https://doi.org/10.1029/2006EO430002. (Washington. DC).

Mobayen, S., 1976. Structure géobotanique du Loute. Acta Ecol. Iran. 1, 73-86.

Mohseni, M., Abbaszadeh, J., Omran, A.N., 2014. Radiation resistant of native Deinococcus spp. isolated from the Lout desert of Iran "the hottest place on Earth" M. Int. J. Environ. Sci. Technol. 11, 1939-1946.

Mosaffa, M., Saleh, F.N., Amirhosseini, Y.K., 2015. Management of natural resources in a changing environment. https://doi.org/10.1007/978-3-319-12559-6.

Nassery, H.R., Kayhomayoon, Z., 2013. Source of salinity in the groundwater of lenjanat plain, Isfahan, Iran. Environ. Earth Sci. 68, 413-427. https://doi.org/10.1007/ s12665-012-1746-4.

Osati, K., Koeniger, P., Salajegheh, A., Mahdavi, M., Chapi, K., Malekian, A., 2014. Spatiotemporal patterns of stable isotopes and hydrochemistry in springs and river flow of the upper Karkheh River Basin, Iran. Isot. Environ. Health Stud. 50, 169-183. https://doi.org/10.1080/10256016.2014.857317.

Parkhurst, D.L., Appelo, C.A.J., 2013. Description of input and examples for PHREEQC version 3 - a computer program for speciation, batch-reaction, one-dimensional transport, and inverse geochemical calculations. U.S. Geol. Surv. Tech. Methods, B. 6https://doi.org/10.1016/0029-6554(94)90020-5. chapter A43 678.

Pilson, M.E., 2012. An Introduction to the Chemistry of the Sea. Cambridge Univ. Press, Cambridge UK. https://doi.org/10.1017/cbo9781139047203.

Porta, J., Lopez-Acebedo, M., Rodriguez, R., 1986. Técnicas y experimentos en 
edafología. Departamento de Publicaciones de la Escuela Técnica Superior de Ingenieros Agrónomos, Universidad de Lérida.

Qin, Y., Li, Y.H., Liu, F., Hou, K.J., Wan, D.F., Zhang, C., 2012. N and O isotopes and the ore-forming mechanism of nitrate deposits in the Turpan-Hami Basin, Xinjiang, China. Sci. China Earth Sci. 55, 213-220. https://doi.org/10.1007/s11430-011 4358-z.

Rahimzadeh, F., Asgari, A., Fattahi, E., 2009. Variability of extreme temperature and precipitation in Iran during recent decades. Int. J. Climatol. https://doi.org/10.1002/ joc.1739.

Rosen, M.R., 1994. The importance of groundwater in playas: a review of playa classifications and the sedimentology and hydrology of playas. In: Rosen, M.R. (Ed.),

Paleoclimate and Basin Evolution of Playa Systems. Geological Society of America.

Rosenthal, E., Magaritz, M., Ronen, D., Roded, R., 1987. Origin of nitrates in the Negev Desert, Israel. Appl. Geochem. 2, 347-354. https://doi.org/10.1016/0883-2927(87) 90050-3.

Schlesinger, W.H., Bernhardt, E., 2013. Biogeochemistry, third ed. Elsevier.

Shirsalimian, M.S., Amoozegar, M.A., Sepahy, A.A., Kalantar, S.M., Dabbagh, R., 2017. Isolation of extremely halophilic archaea from a saline river in the Lut desert of Iran, moderately resistant to desiccation and gamma radiation. Microbiology 86, 403-411. https://doi.org/10.1134/S0026261717030158.
Stone, R., 2016. Some like it hot. Science 354, 1366-1368.

Thomas, J.M., Welch, A.H., Dettinger, M.D., 1996. Geochemistry and isotope hydrology of representative aquifers in the Great Basin region of Nevada, Utah, and adjacent states. 1409-C Prof. Pap.

Tirrul, R., Bell, R., Griffis, R., Camp, V., 1983. The Sistan Suture zone of eastern Iran. Geol. Soc. Am. Bull. 94, 134-150. https://doi.org/10.1130/00167606(1983) $94<134$ :TSSZOE $>2.0$. CO; 2

Trescher, T., 2017. Am hitzepol der Erde. Geo 11, 28-52.

Vengosh, A., 2013. Salinization and Saline Environments, second ed. Elsevier Ltdhttps:// doi.org/10.1016/B978-0-08-095975-7.00909-8. Treatise on Geochemistry: Second Edition.

Welch, K.A., Lyons, W.B., Whisner, C., Gardner, C.B., Gooseff, M.N., Mcknight, D.M., Priscu, J.C., 2010. Spatial variations in the geochemistry of glacial meltwater streams in the Taylor Valley, Antarctica. Antarct. Sci. 22, 662-672. https://doi.org/10.1017/ S0954102010000702.

Wood, W.W., Sanford, W.E., 1990. Ground-water control of evaporite deposition. Econ. Geol. 85, 1226-1235.

Yazdi, A., Emami, M.H., Shafiee, S., 2014. Dasht-e Lut in Iran, the most complete collection of beautiful geomorphological phenomena of desert. Open J. Geol. https:// doi.org/10.4236/ojg.2014.46019. 